The Impact of Accounting Conservatism on Information Asymmetry:Evidence from Egypt

Dr/ Ahmed Hassan Ahmed Ahmed Dr/ Mohamed Ali Shabeeb Ali

\title{
The Impact of Accounting Conservatism on Information Asymmetry:Evidence from Egypt
}

\author{
Dr Ahmed Hassan Ahmed Ahmed
}

Dr Mohamed Ali Shabeeb Ali

\section{Abstract:}

The purpose of the current study is to investigate the impact of accounting conservatism on information asymmetry amongst non-financial companies listed on the Egyptian Exchange throughout the period 2007-2014. More specifically, the study investigates whether or not accounting conservatism assists in alleviating the information asymmetry problem between insiders and outsiders. The study employed one of the most commonly used measures of accounting conservatism, Market-to-Book (MTB) ratio, while information asymmetry was measured using the Bid-Ask spread. In addition, the study takes into account a number of control variables. The study utilised both the univariate and multivariate analysis to provide robust evidence. The results of both the univariate and multivariate analyses reported a negative impact of accounting conservatism on the information asymmetry, but no statistical significance was resulted. With respect to control variables, the results reveal a statistically significant relationship between information asymmetry and trading volume. In addition, the study reveals negative associations with respect to size, leverage and auditor 
The Impact of Accounting Conservatism on Information Asymmetry:Evidence from Egypt

Dr/ Ahmed Hassan Ahmed Ahmed Dr/ Mohamed Ali Shabeeb Ali

type, while positive relationships were reported regarding profitability, liquidity and listing status, however, no statistical significance resulted. To the best of the researcher's knowledge, this is the first study to examine the association between accounting conservatism and information asymmetry in a developing country like Egypt. The results reported here should provide references for companies when preparing their financial statements in the future.

Keywords: Disclosure quality; conservatism; information asymmetry; Egypt

Paper Type: Research Paper 
The Impact of Accounting Conservatism on Information Asymmetry:Evidence from Egypt

Dr/ Ahmed Hassan Ahmed Ahmed Dr/ Mohamed Ali Shabeeb Ali

\section{Introduction}

Throughout accounting history, conservatism or prudence concept is one of the key features of corporate information, being in existence for centuries (Basu, 1997; Watts, 2003a). Starting this discussion would be more informative by outlining what we mean by accounting conservatism. Bliss (1924) asserted that conservatism is to anticipate no profits but anticipate all losses. This adage simply revolves around "accountant's tendency to require a higher degree of verification to recognise good news as gains than to recognise bad news as losses" (Basu, 1997, p. 7). Similarly, Watts and Zimmerman (1986) contend that being conservation implies that disclosing the lowest value of assets among other possible values, while reporting the highest alternative value for liabilities. The IASC (1989) in its framework asserted that due to uncertainties surrounding many events and circumstances, the preparation of financial statements should be done with prudence. Prudence refers to the inclusion of a degree of caution in the exercise of judgment needed in making estimates under conditions of uncertainty (e.g., assets or income are not overstated and liabilities and expenses are not understated).

Advocates of accounting conservatism claim that conservatism serves as a degree of care when uncertainty prevail and it acts as a hinder of management to report overoptimistic results (Ahmed and Duellman, 2007). Moreover, LaFond and Roychowdhury (2008) argued that more separation between 
The Impact of Accounting Conservatism on Information Asymmetry:Evidence from Egypt

Dr/ Ahmed Hassan Ahmed Ahmed

Dr/ Mohamed Ali Shabeeb Ali

ownership and management creates more needs for conservatism. In the same vein, Lafond and Watts (2008) indicated that accounting conservatism could improve the reliability of the disclosed earnings, as they argue that will have lesser options to manipulate and report exaggerated earnings. Furthermore, accounting conservatism is an important mechanism of corporate governance practices and its role in corporate governance is a common theme in the accounting literature (Watts, 2003a; Ahmed and Duellman, 2007). In the same context, Zhang (2008) found that more conservative firms have a lower cost of debt by obtaining lowers interest rates from lenders. Zhang indicated that the benefits of conservatism to lenders come from the fact that conservative firms recognise default risk, which is bad news, in a timelier manner.

Opponents of accounting conservatism argue that conservatism results in biased information and compromises the objectivity of accounting information, which consequently could affect the usefulness of that information in a negative way. In this context, Penman and Zhang (2002) found that unconditional conservatism generates what they called "hidden reserves" that could be eventually released into earnings to achieve management's earnings targets. This implies that accounting conservatism can be employed to facilitate earnings management practices. The conservatism's asymmetric treatment of gains and losses will eventually lead to a systematic understatement in the value of net assets (Watts, 2003a). In this context, Givoly and Hayan (2000) indicated that conservative accounting policies 
The Impact of Accounting Conservatism on Information Asymmetry:Evidence from Egypt

Dr/ Ahmed Hassan Ahmed Ahmed

Dr/ Mohamed Ali Shabeeb Ali

have resulted in a regular decline in firm's profitability. Consequently, uniformed investors who fail to realise the true value of their possessions may sell out too soon (Kim and Pevzner, 2010), resulting in a probable loss. Supporting this view, in their convergent project the International Accounting Standards Board (IASB) and the Financial Accounting Standards Board (FASB) have opposed conservatism concept, resulting in this concept being removed as one of the important qualitative characteristics of accounting information as one of the qualitative characteristics of corporate information (FASB, 2010; IASB, 2010). Nevertheless, Watts (2006) argued that accounting conservatism has been growing in accounts over the last decades and it will continue to prevail in accounting practices, as accounting conservatism is a necessary mechanism to overcome uncertainties surrounding today's business environment (Chi and Wang, 2010).

On the other hand, the agency conflict, resulting from the separation between ownership and management, can be seen as an outcome of information asymmetry in which insiders are more informed than outsiders. In other words, information asymmetry occurs when management or insiders possess information that is relevant in assessing future firm performance which is not available to outsiders especially investors and creditors (Ruch and Taylor, 2015). The information asymmetry can ultimately lead to the adverse selection problem. It has been argued that transparency would alleviate information asymmetry, as this help 
The Impact of Accounting Conservatism on Information Asymmetry:Evidence from Egypt

Dr/ Ahmed Hassan Ahmed Ahmed

Dr/ Mohamed Ali Shabeeb Ali

capital markets to attract external parties, reduces the proportion of private informed transactions, and indirectly decreases information asymmetry. When it comes to the link between accounting conservatism and information asymmetry, LaFond and Watts (2008) argued that conservatism can reduce management incentives to manipulate earnings, alleviate conflicts amongst stakeholders which in turn decrease the information asymmetry problem. In the same context, Chi and Wang (2010) asserted that "conservatism, one of the most prominent characteristics of financial accounting, is actually an efficient way to address the moral hazard problem arising from the asymmetric information among interested stakeholders" ( $p$. 486). Similarly, Garcia Lara et al. (2014) acknowledged this impact explicitly by indicating that: "Conservatism limits earnings manipulation, contributes to enhanced disclosure, and improves investment efficiency. For these reasons, we expect that conservatism ameliorates information asymmetry problems" (p. 195).

Although a substantial body of literature exists on accounting conservatism and information asymmetry, not many of these studies sought to examine the association between accounting conservatism and information asymmetry including: LaFond and Watts (2008); Chi et al. (2009); Chi and Wang (2010); Garcia Lara et al. (2014). The main purpose of the current study is to examine the impact of accounting conservatism on information asymmetry amongst non-financial 
The Impact of Accounting Conservatism on Information Asymmetry:Evidence from Egypt

Dr/ Ahmed Hassan Ahmed Ahmed Dr/ Mohamed Ali Shabeeb Ali

companies listed on the Egyptian Exchange (EGX). The study will proceed further to examine the associations between information asymmetry and some control variables. It is necessary to investigate the impact of accounting conservatism on information asymmetry in the Egyptian context to fully understand the role of conservatism in corporate reporting and provide guidelines to companies when preparing their financial statements.

The remainder of this paper is structured as follows. Section 2 reviews the extant literature in the area and develop the study's hypothesis, while details about data collection process and methods adopted are presented in Section 3. The results are reported in Section 4. Finally, Section 5 concludes the paper by summarising the findings of the existing research and identifying future avenues to explore.

\section{Literature Review and Hypothesis Development}

There is paucity of studies that sought to examine the association between accounting conservatism and information asymmetry in countries with developed capital markets, the situation in developing countries including Egypt is worse. The association between accounting conservatism and information asymmetry was investigated in a study in the US undertaken by Wittenberg-Moerman (2008), who reported that timely recognition of losses (i.e., conditional conservatism) has an adverse impact on the bid-ask spread. This implies that 
The Impact of Accounting Conservatism on Information Asymmetry:Evidence from Egypt

Dr/ Ahmed Hassan Ahmed Ahmed

Dr/ Mohamed Ali Shabeeb Ali

accounting conservatism could reduce the information asymmetry problem. Khan and Watts (2009) sought to examine the link between conservatism and information asymmetry using an event study for a sample of 115,516 firm-years from 1963 to 2005. The findings indicated that an increase in information asymmetry leads to an increase in accounting conservatism. In Taiwan, Chi and Wang (2010) examined the relation between information asymmetry and accounting conservatism for all companies listed on the Taiwan Stock Exchange Corporation (TWSE) during the period from 2000 to 2007. The findings revealed find evidence that accounting conservatism is positively related to the level of and changes in information asymmetry. Similarly, Wang (2013) investigated the impact of accounting conservatism on information asymmetry for a sample totalled 6,387 observation values for the period 2002-2011. The findings revealed that a significant negative relationship between conservation and information asymmetry when corporate conservatism is insufficient, while a positive association was found when accounting earnings is much more conservative. Recently, Garcia Lara et al. (2014) examine the consequences of accounting conservatism for a sample of 63,579 firm-year observations covering the period from 1977 to 2007. The results show that a current increase in firm-level conservatism leads to a reduction in information asymmetries in the following year. Based on the preceding discussion, this study proposes the following hypothesis: 
The Impact of Accounting Conservatism on Information Asymmetry:Evidence from Egypt

Dr/ Ahmed Hassan Ahmed Ahmed Dr/ Mohamed Ali Shabeeb Ali

\section{H1: Accounting conservatism is negatively associated with firm's information asymmetry.}

According to the literature, we would expect the coefficient on the accounting conservatism (MTB ratio) variable to be negative, indicating that accounting conservatism alleviates the information asymmetry problem. For control variables, we expect negative coefficients for trading volume, size, leverage, liquidity and being audited by one of the Big 4 . By contrast, the literature suggests that the coefficients for foreign listing (i.e., being listed in a foreign stock exchange) should be positive, as listing abroad will widen investors base to include not only national investors but also international ones who will not be informed as much as the national investors, which in turn worsen the information asymmetry problem.

Egypt was targeted for the present study as an emerging economy with a major influence on other countries in the Middle East as well as its traditionally strong historical relationships with the world's richest nations (Ahmed, 2013). In addition, Egypt recently confronted many challenges, before, during and following the uprising which led to President Mubarak's resignation in February 2011. The Egyptian economy was badly affected by the civil unrest, and so alleviating the information asymmetry problem might prove important in the economic rebuilding process by attracting foreign investors. The current study also adds to the extant literature by examining the impact 
The Impact of Accounting Conservatism on Information Asymmetry:Evidence from Egypt

Dr/ Ahmed Hassan Ahmed Ahmed

Dr/ Mohamed Ali Shabeeb Ali

of accounting conservatism on information asymmetry in a developing country like Egypt. Furthermore, the current study provides up-to-date evidence concerning the consequences of accounting conservatism. The results presented in this paper should therefore be of interest to regulators and standard-setters charged with developing regulations to control corporate disclosure practices, as these results should provide references for companies when preparing their financial statements in the future.

\section{Data Collection and Method}

This study investigates the impact of accounting conservatism on information asymmetry amongst non-financial companies listed on the EGX. The sample comprises all of the non-financial companies listed on the Egyptian Exchange across the period 2007-2014. After deleting firms with missing data, our final sample includes 85 firms listed on the EGX. We use the Thomson Reuters DataStream database to obtain the data for the investigated variables over the investigated period. As with the prior studies in this area, the outliers of all variables are winsorised to the 5 and 95 percentiles (Francis et al., 2005). Accounting conservatism is measured using the Market-to-Book (MTB) ratio, which is one of the most widely used proxies for determining the extent of accounting conservatism in prior literature (e.g., Beaver and Ryan, 2000; Givoly and Hayn, 2000; Ahmed et al., 2002; Roychowdhury and Watts, 2007, Conway, 2014). Furthermore, as abovementioned, applying conservative 
The Impact of Accounting Conservatism on Information Asymmetry:Evidence from Egypt

Dr/ Ahmed Hassan Ahmed Ahmed

Dr/ Mohamed Ali Shabeeb Ali

accounting policies tend to decrease a firm's book value compared to its market value. Consequently, higher MTB ratios signal a higher level of accounting conservatism and vice versa. In other words, whenever MTB ratio is greater than 1, this signal the existence of accounting conservatism and the larger that ratio the larger the extent of accounting conservatism. With respect to Information asymmetry, the study will use the Bid-Ask spread. Previous studies have developed numerous empirical models to measure information asymmetry by using the bid-ask spread (Chung et al., 2004; Affleck-Graves et al., 2000). The bid-ask spread is established by the dealer(s) (i.e., specialist or market maker) of a firm's stock and it has a transaction cost in the market. "The dealer affords liquidity to the market by being ready to buy at the "bid" price and being ready to sell at the "ask" price" (Demsetz, 1968, p. 40).

\section{Empirical Tests and Results}

\subsection{Descriptive Statistics}

Table 1 below provides summary statistics regarding the variables included in the current analysis. The table shows that the mean value for information asymmetry, measured by BidAsk spread, is 0.054 with a standard deviation of 0.030 . The table also reveals that the mean value for accounting conservatism, measured by Market-to-Book ratio, is 2.44, implying that the sample companies are adopting more conservative accounting policies. With respect to the trading volume, the mean value is about $\mathrm{E} £ 17,813$ with a standard deviation of about $\mathrm{E} £ 43,618$, 
The Impact of Accounting Conservatism on Information Asymmetry:Evidence from Egypt

Drl Ahmed Hassan Ahmed Ahmed

Dr/ Mohamed Ali Shabeeb Ali

which means that there is a great variation amongst the sample companies with respect to their trading volumes. The typical company in the sample has a size of about $E £ 3,352,935$, leverage of $13.70 \%$, return on assets of $10.26 \%$ with current ratio of $2.46 \%$. With respect to the auditor type, 32 out of the 85 companies were audited by one of the Big 4 international accounting firms, while only 8 companies are listed on foreign stock exchanges.

\section{Table 1: Descriptive Statistics for the Sample Companies}

\begin{tabular}{|c|c|c|c|c|c|}
\hline Variables & Mean & StDev & Min & Max & Rang \\
\hline Asymmetry & 0.054 & 0.030 & 0.02 & 0.18 & 0.16 \\
\hline Conservatism & 2.44 & 2.93 & 0.55 & 24.82 & 24.27 \\
\hline TradingV E£ & $17,813.75$ & $43,618.75$ & 1.73 & $278,816.69$ & $278,814.96$ \\
\hline Size E£ & 3,352,935.55 & $7,926,253.80$ & 23,449 & $58,272,047$ & $58,248,598$ \\
\hline Leverage & 13.70 & 14.37 & 0.00 & 58.85 & 58.85 \\
\hline Profitability & 10.26 & 6.70 & -6.10 & 29.62 & 35.72 \\
\hline Liquidity & 2.46 & 2.68 & 0.35 & 17.97 & 17.62 \\
\hline \multirow{2}{*}{ Auditor Type } & \multicolumn{3}{|c|}{ Auditor Big 4} & \multicolumn{2}{|c|}{ Auditor non-Big 4} \\
\hline & \multicolumn{3}{|c|}{33} & \multicolumn{2}{|c|}{52} \\
\hline \multirow{2}{*}{$\begin{array}{l}\text { Listing } \\
\text { Status }\end{array}$} & \multicolumn{3}{|c|}{ Foreign Listing } & \multicolumn{2}{|c|}{ Non-Foreign Listing } \\
\hline & \multicolumn{3}{|c|}{8} & \multicolumn{2}{|c|}{77} \\
\hline
\end{tabular}

Note: This table provides summary statistical information regarding the sample companies. The table shows the mean, standard deviation (StDev), minimum (Min), the maximum 
The Impact of Accounting Conservatism on Information Asymmetry:Evidence from Egypt

Drl Ahmed Hassan Ahmed Ahmed

Dr/ Mohamed Ali Shabeeb Ali

(Max) and the rang values for the different variables included in the current analysis. Information asymmetry $=($ ask price - bid price $) /(($ ask price + bid price $) / 2)$; Conservatism $=$ Market-ToBook ratio ((Market Price-High + Market Price-Low / 2) / Book Value Per Share); TradingV = Trading Volume Size = Market Capitalisation (Market Price-Year End * Common Shares Outstanding $)$; Leverage $=($ Short Term Debt $\&$ Current Portion of Long Term Debt + Long Term Debt) / Total Assets * 100; ROA $=$ Return on Assets ((Net Income before Preferred Dividends + ((Interest Expense on Debt-Interest Capitalized) * (1-Tax Rate))) / Average of Last Year's and Current Year's Total Assets * 100), Liquidity $=$ Current Assets-Total / Current Liabilities-Total. Auditor Type $=$ Dummy variable that takes the value of 1 if the company is audited by one of the Big 4, 0 otherwise; Listing Status = Dummy variable that takes the value of 1 if the company's shares are listed in a foreign stock exchange, 0 otherwise.

\subsection{Univariate Analysis}

Tables 2 and 3 below provide the results of the Pearson correlations for the continuous variables and the Spearman's rho for the non-continuous variables throughout the investigated period. The results shows that there is a negative, but not significant, association between information asymmetry and accounting conservatism, as can be seen from Table 2. With respect to the control variables, the results show that information asymmetry is significantly negatively associated with firm's 
The Impact of Accounting Conservatism on Information Asymmetry:Evidence from Egypt

Drl Ahmed Hassan Ahmed Ahmed

Dr/ Mohamed Ali Shabeeb Ali

trading volume. Furthermore, information asymmetry has a negative relationship with firm leverage, although the co-efficient is only significant at $5 \%$ confidence level, as shown in Table 2 below. The findings also reveal negative association between information asymmetry and company size, while positive relationships were reported concerning profitability and liquidity, although no statistical significance was reported with respect to any of these relationships. Table 3 reports the results with results with respect to the non-continues variables. The evidence reported in table 3 indicates that information asymmetry has a significant negative association with auditor type. In this regard, agency theory hypothesised that auditing helps to mitigate any conflicts of interest that exist between agents and shareholders (Xiao et al., 2004). Therefore, it is argued that companies with higher agency costs may try to alleviate this problem by employing one of the Big-4 international auditing firms (Giner, 1997). On the other hand, to maintain their reputation, Big-4 audit firms have an incentive to protect their independence by means of extensive disclosure requirements and procedures, as they require their clients to provide greater transparency (Bonsón and Escobar, 2006), thereby reducing information asymmetry problem. On the other hand, the results indicate that there is a positive association with respect to the listing status. These results may be linked to the fact that having their shares traded in foreign exchanges, companies are required not only to comply with the rules of their home country, but also those of the other exchanges where they are listed. Indeed, widening the investor 
The Impact of Accounting Conservatism on Information Asymmetry:Evidence from Egypt

base beyond the national borders, may worsen the information asymmetry problem.

Table 2: Pearson Correlation between Information Asymmetry and the Continuous Independent Variables

\begin{tabular}{|c|c|c|c|c|c|c|c|}
\hline & B-A & MTB & TVol & Size & Leve & ROA & Liq \\
\hline B-A & 1.000 & & & & & & \\
\hline MTB & -0.166 & 1.000 & & & & & \\
\hline TVol & $-\mathbf{0 . 3 8 9 * *}$ & $\mathbf{0 . 1 3 0}$ & 1.000 & & & & \\
\hline Size & $-\mathbf{0 . 1 5 5}$ & $\mathbf{0 . 1 3 0}$ & $\mathbf{0 . 0 8 7}$ & 1.000 & & & \\
\hline Lev & $-\mathbf{0 . 1 9 6} *$ & $-\mathbf{0 . 0 2 3}$ & $\mathbf{0 . 2 2 2} *$ & $\mathbf{. 3 2 4} * *$ & 1.000 & & \\
\hline ROA & $\mathbf{0 . 1 7 5}$ & $\mathbf{0 . 0 8 6}$ & $-\mathbf{0 . 1 2 7}$ & $\mathbf{0 . 1 1 2}$ & $-\mathbf{0 . 2 4 3} *$ & 1.000 & \\
\hline Liq & $\mathbf{0 . 0 8 8}$ & $\mathbf{- 0 . 0 2 2}$ & $-\mathbf{0 . 0 0 4}$ & $-\mathbf{0 . 1 1 0}$ & $-\mathbf{0 . 2 3 2}$ & $\mathbf{0 . 0 2 2}$ & $\mathbf{1 . 0 0 0}$ \\
\hline
\end{tabular}

$* *=$ Correlation is significant at the 0.01 level (1-tailed).

$*=$ Correlation is significant at the 0.05 level (1-tailed).

Table 3: Spearman's rho Correlation between Information Asymmetry and the Non-Continuous Independent Variables

\begin{tabular}{|c|c|c|c|}
\hline & Asymmetry & Auditor & $\begin{array}{c}\text { Foreign } \\
\text { Listing }\end{array}$ \\
\hline Asymmetry & $\mathbf{1 . 0 0 0}$ & & \\
\hline Auditor & $-\mathbf{0 . 2 0 6 *}$ & 1.000 & \\
\hline Foreign & $\mathbf{0 . 0 2 3}$ & $\mathbf{0 . 2 4 9 *}$ & $\mathbf{1 . 0 0 0}$ \\
\hline
\end{tabular}

$*=$ Correlation is significant at the 0.05 level (1-tailed). 
The Impact of Accounting Conservatism on Information Asymmetry:Evidence from Egypt

Dr/ Ahmed Hassan Ahmed Ahmed Dr/ Mohamed Ali Shabeeb Ali

\subsection{Multivariate Analysis}

The results of the univariate analysis suggested a significant relationship between three of the eight variables included in the current analysis. A multivariate linear regression analysis was therefore undertaken to examine the relationships in terms of causality. The regression equation used is as follows:

$$
\begin{aligned}
& \text { Asymmetry } \\
& \qquad \begin{array}{l}
=\beta_{0}+\beta_{1} \text { MTB }+\beta_{2} \text { Trading Volume } \\
++\beta_{3} \text { Size }+\beta_{4} \text { Leverage }+\beta_{5} \text { Profitability } \\
+\beta_{6} \text { Liquidity }+\beta_{7} \text { Auditor } \\
+\beta_{8} \text { Foreign Listing }+\varepsilon_{I}
\end{array}
\end{aligned}
$$

The results of the regression analysis are reported in Table 4 below. Regression diagnostics were run to test for multicollinearity amongst the independent variables. As can be seen from Table 4 , the figures for the tolerance and variance inflation factor did not reveal any multicollinearity problems. In line with the evidence of the univariate analysis, the findings of the multivariate analysis reveal a negative association between information asymmetry and accounting conservatism, although statistical significance not resulted. This result is consistent with prior studies that suggested that accounting conservatism alleviates the information asymmetry problem. The findings also reveal a statistically significant negative relationship between information asymmetry and trading volume, again this result 
The Impact of Accounting Conservatism on Information Asymmetry:Evidence from Egypt

Dr/ Ahmed Hassan Ahmed Ahmed Dr/ Mohamed Ali Shabeeb Ali

support those of the univariate analysis. Unlike the results reported in the univariate analysis, no significance was reported concerning the relationship between information asymmetry and leverage and auditor type, but the sign is still negative. The results for the remaining control variables are consistent with those found in the univariate analysis.

Table 4: The Regression Analysis

\begin{tabular}{|c|c|c|c|}
\hline & $\begin{array}{l}\text { Information } \\
\text { Asymmetry }\end{array}$ & Tolerance & VIF \\
\hline \multirow[t]{2}{*}{ Constant } & $0.056^{* * *}$ & & \\
\hline & 6.615 & & \\
\hline \multirow[t]{2}{*}{ Conservatism } & -0.001 & 0.905 & 1.105 \\
\hline & -1.031 & & \\
\hline \multirow[t]{2}{*}{$\begin{array}{l}\text { Trading } \\
\text { Volume }\end{array}$} & $-0.000^{* * *}$ & 0.819 & 1.221 \\
\hline & -2.861 & & \\
\hline \multirow[t]{2}{*}{ Size } & -0.000 & 0.604 & 1.656 \\
\hline & -0.830 & & \\
\hline \multirow[t]{2}{*}{ Leverage } & -0.000 & 0.672 & 1.488 \\
\hline & -0.200 & & \\
\hline \multirow[t]{2}{*}{ Profitability } & 0.001 & 0.881 & 1.135 \\
\hline & 1.341 & & \\
\hline \multirow[t]{2}{*}{ Liquidity } & 0.001 & 0.932 & 1.074 \\
\hline & 0.518 & & \\
\hline \multirow[t]{2}{*}{ Auditor Type } & -0.004 & 0.747 & 1.338 \\
\hline & -0.499 & & \\
\hline
\end{tabular}


The Impact of Accounting Conservatism on Information Asymmetry:Evidence from Egypt

Dr/ Ahmed Hassan Ahmed Ahmed Dr/ Mohamed Ali Shabeeb Ali

\begin{tabular}{|c|c|c|c|}
\hline Foreign Listing & 0.001 & 0.582 & 1.717 \\
\hline & 0.063 & & \\
\hline No & \multicolumn{3}{|c|}{85} \\
\hline Adjusted R $\mathbf{R}^{2}$ & $12.5 \%$ \\
\hline F Value & \multicolumn{3}{|c|}{2.496} \\
\hline
\end{tabular}

Note: The Table shows the results of the regression analysis. For variable description, see Table $1 .^{* * *} \mathrm{p}$-value $<0.01{ }^{* *} \mathrm{p}$-value $<0.05,{ }^{*}$ p-value $<0.1$.

\section{Discussion, Conclusion and Future Research}

Information asymmetry and accounting conservatism are one of the most extensively researched topics in the accounting literature in countries with developed capital markets, but this is not the case with respect to developing countries, including Egypt. Therefore, the present study thought to fill this void in the extant literature. The purpose of the study is to investigate the impact of accounting conservatism on the information asymmetry problem amongst non-financial companies listed on the Egyptian Exchange covering the period from 2007 to 2014. The study also examines the relationships with respect to some control variables that appear in the extant literature in this specific area.

Our results reveal that accounting conservatism has a negative impact on information asymmetry amongst companies included in the present analysis, although the relationship was not significant, this evidence indicate that accounting 
The Impact of Accounting Conservatism on Information Asymmetry:Evidence from Egypt

Drl Ahmed Hassan Ahmed Ahmed

Dr/ Mohamed Ali Shabeeb Ali

conservatism can be utilised as an accounting policy for alleviating the information asymmetry problem between insiders and outsiders. Furthermore, the study reported a significant negative association between trading volume and the extent of information asymmetry. The results for the remaining control variables, although none of the cases resulted in statistical significance, the reported evidence is still in line with the findings of the extant literature in this area. More specifically, the study reported negative associations concerning company size, leverage and being audited by one of the Big 4 accounting firms, while positive relationships were revealed regarding profitability, liquidity and being listed in a foreign exchange.

Given the scarcity of accounting research that examines the impact of accounting conservatism on information asymmetry especially in developing countries, including Egypt, the current study contribute to the work that has been undertaken in this area. Furthermore, the current study provides recent evidence concerning the association between accounting conservatism and information asymmetry. The data is up-to-date and from a source that has not been examined in the past. The results of the present analysis have a number of practical implications for both national (Egypt) and international corporations. For example, the results show that foreign listing has a positive impact on the information asymmetry problem, which might discourage foreign investors from investing in Egyptian companies and taking into account the fact that the Egyptian economy was badly affected by the 
The Impact of Accounting Conservatism on Information Asymmetry:Evidence from Egypt

Dr/ Ahmed Hassan Ahmed Ahmed Dr/ Mohamed Ali Shabeeb Ali

civil unrest. Therefore, companies should be encouraged to engage in various communication channels with foreign investors including the disclosure of corporate information via their websites, and so online reporting practices might prove important in the economic re-building process by providing the detailed and timely information necessary to alleviate the information asymmetry problem and attract foreign investment.

Taking into account the idea that this kind of research is not mature yet especially in developing countries, so more studies are required in this area. First, an informative expansion of the present study could investigate the views of interested parties concerning the other factors that might have an impact on alleviating the information asymmetry problem. A second expansion might involve a cross-country comparative analysis of factors that influence information asymmetry in the Middle East and North Africa (Mena) region. In this regard, it has been argued that analyses of prior literature across the broad field of accounting has tended to group these nations together, there are many differences in economic, culture and political contexts and international replication of the work could yield important insights. 
The Impact of Accounting Conservatism on Information Asymmetry:Evidence from Egypt

Dr/ Ahmed Hassan Ahmed Ahmed Dr/ Mohamed Ali Shabeeb Ali

\section{References}

Ahmed, A. H. (2013) Corporate Internet Reporting in Egypt: Practices and Perceptions. Unpublished PhD dissertation, University of Dundee, UK.

Ahmed, A. S., \& Duellman, S. (2007) Evidence on the role of accounting conservatism in corporate governance. Journal of Accounting and Economics 43, 411-437.

Andreou, Panayiotis C., Cooper, I., Louca, C. \& Philip, D. (2015) Does Accounting Conservatism Mintigate Bank's Crash Risk. Working Paper Present at British Accounting and Finance Conference, University Place, Manchester, March 23-25, 2015.

Basu, S. (1997) The conservatism principle and the asymmetric timeliness of earnings. Journal of Accounting and Economics 24 (1): 3-37.

Beattya, A., Weberb, J,. \& Yu, J. (2008) Conservatism and Debt. Journal of Accounting and Economics, 45, pp. 154-174.

Beaver, W., \& Ryan, S. (2005). Conditional and unconditional conservatism: Concepts and modelling. Review of Accounting Studies, Vol 10(2-3), 269-309.

Bliss, J. H. (1924). Management through accounts. New York: The Ronald Press Co.

Chai, Q., \& Zhao, H. (2014) Accounting Conservatism and the Choice of Method of Payment in Corporate Acquisitions. Working Paper Presented at British Accounting and Finance Conference, London School of Economics, London, 14-16 April.

Chi, W. \& Wang, C. (2010) Accounting conservatism in a setting of Information Asymmetry between majority and minority shareholders. The International Journal of Accounting, Vol 45(4), pp. 465-489. 
The Impact of Accounting Conservatism on Information Asymmetry:Evidence from Egypt

Dr/ Ahmed Hassan Ahmed Ahmed Dr/ Mohamed Ali Shabeeb Ali

Conway, E. (2014) Is UK Financial Reporting Becoming Less Conservative? Working Paper Presented at British Accounting and Finance Conference, London School of Economics, London, 14-16 April.

FASB (Financial Accounting Standards Board). (2010). Statement of financial accounting concepts No 8. Conceptual Framework for Financial Reporting. Norwalk, CT: Author.

FASB (Financial Accounting Standards Board). (2010). Statement of financial accounting concepts No 8. Conceptual Framework for Financial Reporting. Norwalk, CT: Author.

Francis, J., LaFond, R., Olsson, P. \& Schipper, K. (2005) The market pricing of accruals quality. Journal of Accounting and Economics, 39(2), pp 295-327.

International Accounting Standards Committee (1989) Framework for the Preparation and Presentation of Financial Statements. IASC, London.

International Accounting Standards Board (2010) The Conceptual Framework for Financial Reporting (The IFRS Framework). IASB, London.

Givoly, D. \& Hayn, C. (2000) The changing time-series properties of earnings, cash flows and accruals: has financial reporting become more conservative? Journal of Accounting and Economics 29 (3), 287-320.

Garc1'a Lara, J. M., Garc1'a Osma, B., \& Penalva, F. (2014) Information Consequences of Accounting Conservatism. European Accounting Review, 3 (2), pp. 173-198. 
The Impact of Accounting Conservatism on Information Asymmetry:Evidence from Egypt

Dr/ Ahmed Hassan Ahmed Ahmed Dr/ Mohamed Ali Shabeeb Ali

Jenkins, D. S., Kane, G. D. \& Velury, U. (2009) Earnings Conservatism and Value Relevance Across the Business Cycle. Earnings Management: Evidence Based on Hong Kong Firms. Journal of Business Finance \& Accounting, Vol. 36, No. 9-10, pp. 1041-1058.

Kim, B. H., \& Pevzner, M. (2010) Conditional accounting conservatism and future negative surprises: An empirical investigation. Journal of Accounting and Public Policy, Vol 29(4), pp. 311-329.

LaFond, R. \& Roychowdhury, S. (2008) Managerial Ownership and Accounting Conservatism. Journal of Accounting Research, Vol 46(1), pp. 101-135.

LaFond, R. \& Watts, R. (2008) The Information Role of Conservatism. The Accounting Review 83, 447-478.

Penman, S. H., \& Zhang, X. (2002). Accounting conservatism, the quality of earnings, and stock returns. The Accounting Review, 77(2), 237264.

Ramalingegowda, S. \& Yu, Y. (2012) Institutional ownership and conservatism. Journal of Accounting and Economics, Vol 53, pp. 98114.

Roychowdhury, S. \& Watts, R. (2007) Asymmetric timeliness of earnings, market-to-book and conservatism in financial reporting. Journal of Accounting and Economics 44, 2-31.

Roychowdhury, S. \& Yu, Y. (2012) Institutional ownership and conservatism. Journal of Accounting and Economics 53, pp. 98-114.

Ruch, G. W., \& Taylor, G. (2015) Accounting conservatism: A review of the literature. Journal of Accounting Literature, Vol 34, pp. 17-38.

The Egyptian Exchange (2012) The Annual Report. EGX, Cairo, Egypt. [online] http://www.egx.com.eg/getdoc/f0d50a9e-058d-4d8c-b6ae- 
The Impact of Accounting Conservatism on Information Asymmetry:Evidence from Egypt

Dr/ Ahmed Hassan Ahmed Ahmed Dr/ Mohamed Ali Shabeeb Ali

80afb9f398ee/Annual-Report-2012_en.aspx, accessed on 02/12/2015.

Wang, M., Xiao, J. \& Zhu, J. (2014) What Shape the Accounting Conservatism of Private Firms? Working Paper Presented at British Accounting and Finance Conference, London School of Economics, London, 14-16 April.

Watts, R. (2003a) Conservatism in accounting. Part I: explanations and implications. Accounting Horizons Vol 17, pp. 207-221.

Watts, R. (2003b). Conservatism in accounting - Part II: Evidence and research opportunities. Accounting Horizons, 17(4), 287-301.

Watts, R. (2006). What has the Invisible Hand Achieved? Available online at: http://ssrn.com/abstract=879811, accessed on 10/12/2015.

Watts, R., \& Zimmerman, J. (1986) Positive accounting theory. Englewood Cliffs, NJ: Prentice Hall.

Wittenberg-Moerman, R. (2008). The role of information asymmetry and financial reporting quality in debt trading: Evidence from the secondary loan market. Journal of Accounting and Economics, 46(2), 240-260.

Wu, Z. \& Roberts, C. (2014) Empirical study of the influence of accounting standards on conditional conservatism: Evidence from China. Working Paper Presented at British Accounting and Finance Conference, London School of Economics, London, 14-16 April.

Xu, R., Taylor, G., \& Dugan, M. (2007). Review of real earnings management literature. Journal of Accounting Literature, 26, 195228.

Zhang, J. (2008). The contracting benefits of accounting conservatism to lenders and borrowers. Journal of Accounting and Economics, 45(1), 27-54. 